\title{
DEGRADAÇÃO DE ÁREAS DE NASCENTES NA SUB-BACIA HIDROGRÁFICA DO CÓRREGO DAS PITAS-MT: O QUE PENSAM OS PEQUENOS PRODUTORES RURAIS?
}

\author{
Vanusa Mariano Santiago Schiavinato \\ Universidade do Estado de Mato Grosso, Pós-Graduação em Geografia, Cáceres-MT, Brasil \\ vsanstki@hotmail.com \\ Alfredo Zenen Dominguez González \\ Universidade do Estado de Mato Grosso, Pós-Graduação em Geografia, Cáceres-MT, Brasil \\ alfredozdg@gmail.com
}

\begin{abstract}
RESUMO
Considerando os efeitos da degradação das nascentes na disponibilidade de recursos hídricos em Mato Grosso, a pesquisa objetivou identificar a percepção de uma amostra de pequenos produtores rurais da sub-bacia hidrográfica do córrego das Pitas sobre o manejo das suas áreas de nascentes. A metodologia utilizada compreendeu observações in loco e aplicação de questionário a produtores selecionados, intencionalmente. Os resultados indicam que a intensa ocupação da sub-bacia atingiu todas as nascentes estudadas, onde a diversidade de usos provocou impactos ambientais que explicam a sua atual degradação. Entretanto, a percepção dos proprietários sobre o manejo das suas nascentes é inadequada, associado, principalmente, ao baixo nível de escolaridade, falta de assistência técnica e cursos profissionalizantes, e insuficiente fiscalização das ações de proteção estabelecidas na legislação vigente. Conclui-se que é necessário propor ações prioritárias orientadas a estimular uma adequada gestão ambiental nas propriedades rurais, envolvendo os atores sociais que poderiam protagonizar a sua implementação.
\end{abstract}

Palavras-chave: Ocupação. Impactos ambientais. Avaliação. Percepção.

\section{DEGRADACIÓN DE ÁREAS DE NACIENTES EN LA SUBCUENCA HIDROGRÁFICA DEL ARROYO LAS PITAS-MT: QUE PIENSAN LOS PEQUEÑOS PRODUCTORES RURALES?}

\begin{abstract}
RESUMEN
Considerando los efectos de la degradación de nacientes de cuerpos de agua en la disponibilidad de recursos hídricos de Mato Grosso, el objetivo de esta investigación fue identificar la percepción de una muestra de pequeños productores rurales de la subcuenca del arroyo Las Pitas sobre el manejo de sus áreas de nacientes. La metodología utilizada incluyó observaciones in situ y aplicación de cuestionario a productores seleccionados, intencionalmente. Los resultados indican que la intensa ocupación de la subcuenca afectó las nacientes estudiadas, donde la diversidad de usos provocó impactos ambientales que explican su actual degradación. Además, la percepción de los propietarios sobre el manejo de sus nacientes es inadecuada, asociado principalmente al bajo nivel de escolaridad, falta de asistencia técnica e cursos profesionalizantes e insuficiente fiscalización de las acciones de protección establecidas en la legislación vigente. Se concluye que es necesario proponer acciones prioritarias orientadas a estimular una adecuada gestión ambiental en las propiedades rurales, envolviendo a los actores sociales que podrían protagonizar su implementación.
\end{abstract}

Palabras clave: Ocupación. Impactos ambientales. Evaluación. Percepción.

\section{INTRODUÇÃO}

A crescente ocupação das bacias hidrográficas, associada ao acelerado crescimento populacional, que foi acompanhado da ocupação desordenada de novas áreas para a agricultura, a pecuária e a expansão urbana e industrial experimentada a partir dos anos 1950, gerou um crescimento exorbitante da demanda e uma progressiva degradação da qualidade da água (REBOUÇAS et. al.,

$\begin{array}{lllll}\text { Caminhos de Geografia } & \text { Uberlândia-MG } & \text { v. 21, n. } 74 & \text { Abr/2020 } & \text { p. 295-312 }\end{array}$ Página 295


2006; NASCIMENTO e FERNANDES, 2017), além de alterar a morfologia e a dinâmica fluvial pelo aumento do fluxo de materiais transportados para os leitos fluviais contribuindo para 0 seu assoreamento (CHAVES e SANTOS, 2009).

Neste sentido, autores como Magalhães Júnior (2000), Diegues (2000), Tundisi et al. (2003) e Rebouças et al. (2006) têm destacado os efeitos do uso indiscriminado dos recursos hídricos e a insuficiente conservação, na degradação da qualidade da água, inviabilizando o seu uso e contribuindo para a escassez de água que está assolando diversas regiões do mundo. No Brasil, com uma desigual distribuição deste recurso entre as diferentes regiões, essa escassez vem se agravando gradativamente (TUNDISI, 2003). Essa degradação atinge às nascentes, que são essenciais para manter o equilíbrio hidrológico das correntes fluviais, podendo levar ao seu desaparecimento, com a conseguinte redução da disponibilidade hídrica (CASTRO, 2001, apud PEREIRA, 2012).

Na região sudoeste do estado de Mato Grosso, o perigo de escassez hídrica advém, dentre outras possíveis causas, do desmatamento nas áreas de nascentes nas propriedades rurais (mesmo os proprietários dependendo delas para a sustentação das suas atividades), provocando impactos ambientais como o assoreamento de canais fluviais, a poluição da água e o desaparecimento de algumas nascentes (TUCCI, 2001; SILVA, 2009).

$O$ antes exposto indica a necessidade de realizar profundas mudanças na forma em que estão sendo manejadas as áreas de nascentes. Porém, com base em Whyte (1978) podemos dizer que para fazer acontecer tais mudanças deve-se partir do conhecimento sobre o que pensam os proprietários rurais sobre as nascentes, porque isso irá influenciar no seu comportamento com elas. Dai que um objetivo da pesquisa que se apresenta fosse identificar a percepção de uma amostra de pequenos produtores rurais da sub-bacia hidrográfica do córrego das Pitas sobre o manejo das suas áreas de nascentes.

O tema da percepção humana tem sido amplamente tratado na literatura científica; assim, para autores como Day (1979), Lencioni (2003) e Marcomin e Sato (2016) o relacionamento dos seres humanos com a natureza que os rodeia, determina a formação da sua percepção do mundo e a toma de consciência sobre ele; ou seja, a percepção faz com que a pessoa se torne parte das coisas, sem conseguir se desprender delas (MERLEAU-PONTY, 1999). Isto ocorre porque, como afirmara YiFu.Tuan (1980), a percepção é a resposta dos sentidos aos estímulos externos. Assim, todas as "[...] expectativas, anseios, satisfações e insatisfações, julgamentos e condutas do homem está relacionada ao espaço onde está inserido" (VASCO e ZAKRZEVSKI, 2010, p. 18). Neste sentido, a avaliação das ações humanas sobre o seu lugar no ambiente se torna possível quando há reflexão sobre essa relação homem-ambiente (MARIN et. al., 2003).

Porém, como destacado por autores como Cardozo (2009) e Mariaet al. (2011), o contexto onde os seres humanos estão inseridos faz com que eles percebam o mesmo fenômeno com base em critérios de relevância divergentes, pois a percepção depende das características individuais da pessoa (como: gênero, escolaridade, profissão, local de moradia e realidade sociocultural vivenciada); ou seja, suas percepções mudam conforme o contexto sociocultural onde estão inseridos.

Para compreender o comportamento dos seres humanos em sua interação com a natureza durante o processo de construção do espaço geográfico é importante conhecer a sua percepção ambiental, tendo em vista que é através da percepção ambiental que se obtêm conhecimentos socialmente elaborados (JODELET, 2001). Macedo (2005), afirma que o uso da percepção ambiental permite compreender o relacionamento do homem com a natureza e o seu grau de consciência no que tange à problemática ambiental. Neste sentido, a transformação do espaço se dá conforme se transformam as nossas ações, vivências e consciências (SUERTEGARAY, 2005).

A mesma ideia apresenta Okamoto (1996), quando destaca a percepção ambiental como fenômeno que agrega a psicologia com a sociologia no intuito de compreender as expectativas e o nível de satisfação da população em ralação com o meio ambiente, a qualidade de vida e o bem-estar social.

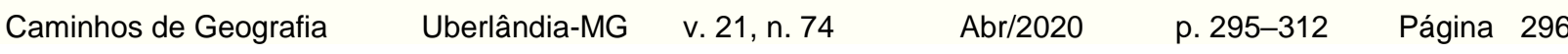


Estudos sobre percepções ambientais buscam uma participação maior da comunidade para o desenvolvimento e planejamento regional na tentativa de utilizar os recursos naturais com mais racionalidade, afirma Whytte (1978). Principalmente quando se trata de sistemas hídricos nos quais as áreas de preservação vêm sofrendo deterioração e poluição em decorrência da antropização, conforme ressaltam Cabanelas e Moreira (2007).

Paralelamente, o conhecimento da percepção ambiental permite subsidiar a elaboração de projetos de educação ambiental e programas de gestão ambiental. Portanto, este tipo de estudo deve fazer parte de projetos de pesquisa no que tange ao gerenciamento de ecossistemas e da relação homemambiente (MAROTI et. al., 2000). Ou seja, a melhoria da qualidade ambiental das áreas de nascentes é possível quando se conhece a percepção dos agentes sociais envolvidos com a sua utilização.

\section{Área de estudo}

A área de estudo corresponde à sub-bacia hidrográfica do córrego das Pitas, um dos afluentes do rio Juru que, pela sua vez, verte suas águas no rio Paraguai. Os pontos extremos desta sub-bacia se localizam nas latitudes $15^{0} 18^{\prime} 00^{\prime \prime} \mathrm{S}$ e $15^{\circ} 54^{\prime} 00^{\prime \prime} \mathrm{S}$, e nas longitudes $58^{\circ} 14^{\prime} 30^{\prime \prime} \mathrm{O}$ e $58^{\circ} 33^{\prime} 45^{\prime \prime} \mathrm{O}$ (Figura 1).

Figura 1 - Mapa da área de estudos.
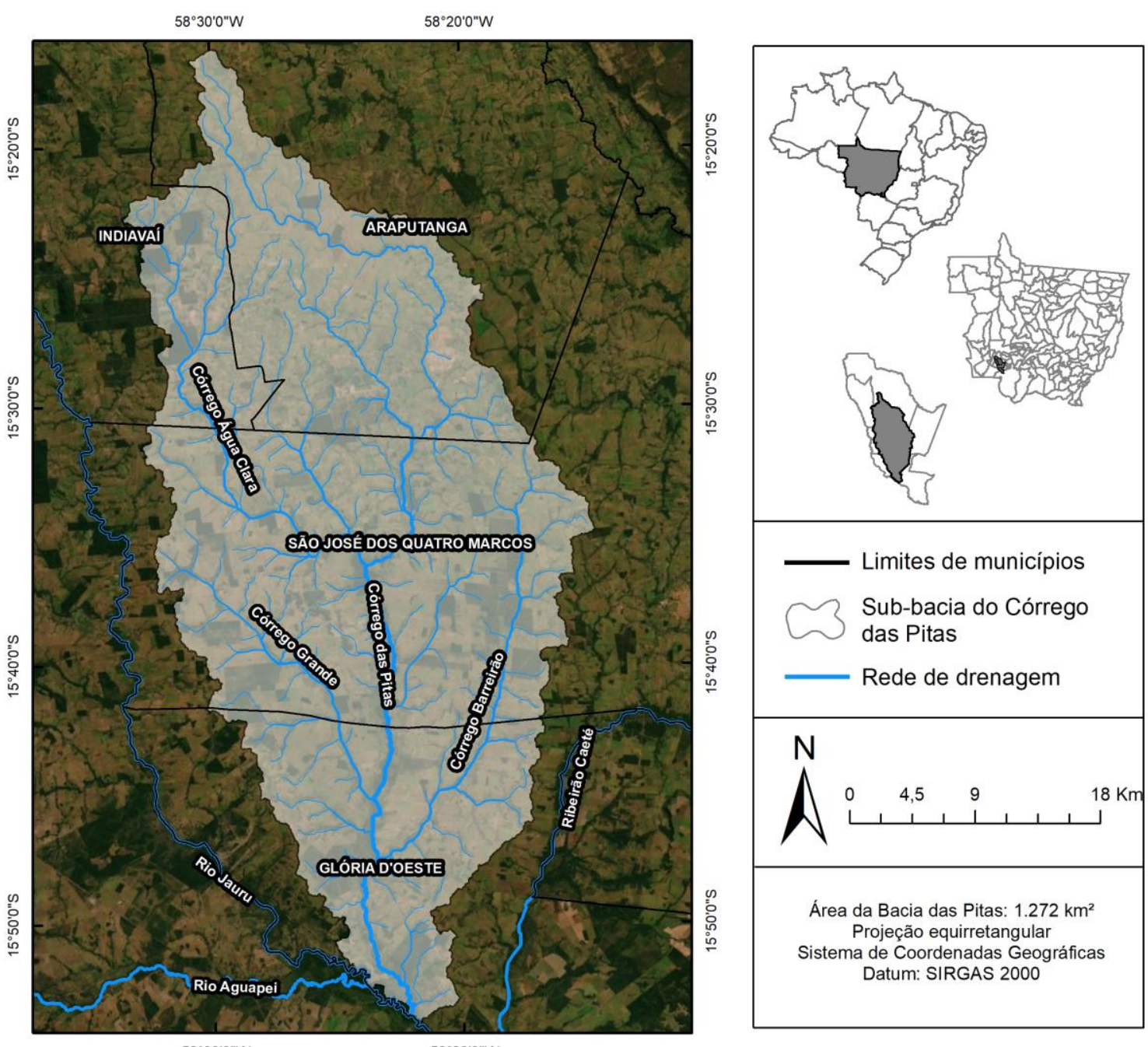

Fonte - Autores (2018). 
Segundo autores como Silva (2009) e Marostega (2012), nesta sub-bacia predominam os afloramentos de rochas metamórficas proterozóicas (Complexos Alto Guaporé e Alto Jauru), granitoides (Suítes Intrusivas Alvorada e Água Clara) e depósitos de cobertura detrítico-lateríticos cenozoicos. O clima é Tropical de Savana (Aw), com estações chuvosa e seca de igual duração. A sub-bacia se situa sobre o Planalto Alto Jauru-Rio Branco, com relevo ondulado e numerosas formas relictas (serras e cristas esculpidas em intrusões ígneas). Estas características levaram à formação de uma densa rede hídrica. As principais classes de solos na área são: Argissolo Vermelho-Amarelo Eutrófico, Latossolo Vermelho Eutrófico, Latossolo Vermelho Distrófico e Neossolo Quartzarênico Órtico. Das formações de vegetação originais (Floresta Estacional Semidecidual, Savana Arbórea Aberta e Mata de galeria) apenas restam fragmentos devido à sua substituição por culturas e pastagens.

\section{METODOLOGIA}

Inicialmente se identificaram as principais áreas de nascentes da sub-bacia, com base na análise de produtos cartográficos da área, a interpretação de imagens de satélite Landsat 5-sensor TM do ano de 2016 e visitas a campo para verificar a variabilidade sazonal de vazões nas épocas de chuva (dezembro de 2017 a fevereiro de 2018) e seca (julho a setembro de 2018). Assim, foram identificadas 875 áreas de nascentes, das quais 310 cumprem com os critérios de seleção estabelecidos pelos autores do presente estudo : (1) serem nascentes perenes; (2) estarem desmatadas (o que facilita a sua degradação ambiental); (3) se localizarem em diferentes setores (alto, médio e baixo curso) da sub-bacia do córrego das Pitas, e (4) se localizarem em propriedades de pequenos produtores rurais (fato que poderia favorecer a implementação de medidas de proteção e/ou recuperação nas suas áreas de nascentes). A seguir foi retirada uma amostra constituída por $10 \%$ das 310 nascentes supracitadas, que cumprem os requisitos. Porém, foi acrescentada a nascente do Lago Azul (porque fornece a água que abastece o lago construído na cidade de Araputanga para o lazer da população), sendo pesquisadas 32 áreas de nascentes através de levantamentos de campo. Esses levantamentos permitiram confirmar sua localização em pequenas propriedades rurais, marcar as coordenadas utilizando aparelho GPS, caracterizá-las com base na Ficha Cadastral de Nascentes (COVRE, 2010) e identificar as atividades humanas geradoras de impactos ambientais (diretos e indiretos) nas áreas de nascentes selecionadas.

Finalmente, para identificar a percepção dos produtores rurais sobre o manejo das nascentes na subbacia foi aplicado um questionário aos proprietários de áreas de nascentes, elaborado com base em autores como Filgueira et al. (2010); Menezes (2010); Ferronato (2016) e Américo et al. (2012). As perguntas foram estruturadas em blocos, sendo que as do bloco I objetivaram obter o perfil socioeconômico da propriedade rural; as do bloco II, conhecer a percepção dos proprietários sobre as nascentes existentes dentro da propriedade; e as do bloco III, conhecer as práticas de manejos utilizadas nas propriedades rurais. A seleção dos participantes se deu pela escolha intencional, buscando selecioná-los de acordo com os objetivos da pesquisa e o seu conhecimento da realidade pesquisada.

\section{RESULTADOS E DISCUSSÃO}

\section{Degradação das áreas de nascentes estudadas}

A influência das atividades desenvolvidas nas propriedades rurais na geração de impactos ambientais nas áreas de nascentes foi determinada com base em levantamentos de campo, os quais permitiram 
identificar as principais ações antrópicas que têm provocado impactos ambientais nas nascentes (Quadro 1).

Quadro 1 - Influencia das atividades realizadas nas propriedades rurais na geração de impactos ambientais nas áreas de nascentes.

\begin{tabular}{|c|c|c|c|c|}
\hline \multirow{2}{*}{$\begin{array}{l}\text { Atividades } \\
\text { humanas }\end{array}$} & \multicolumn{4}{|c|}{ Impactos ambientais } \\
\hline & Diretos & $\begin{array}{l}\text { Nascentes } \\
\text { impactadas } \\
\text { (\% do total) }\end{array}$ & Indiretos & $\begin{array}{l}\text { Nascentes } \\
\text { impactadas } \\
\text { (\% do total) }\end{array}$ \\
\hline \multirow{5}{*}{$\begin{array}{c}\text { Desmatamento } \\
\text { da } \\
\text { área de } \\
\text { nascentes }\end{array}$} & $\begin{array}{c}\text { Aumento da energia } \\
\text { dos fluxos } \\
\text { superficiais. }\end{array}$ & 71,9 & Assoreamento & 56,3 \\
\hline & $\begin{array}{c}\text { Destruição de } \\
\text { habitats naturais }\end{array}$ & 84,4 & Erosão induzida do solo & 71,9 \\
\hline & \multirow{3}{*}{$\begin{array}{c}\text { Perda de } \\
\text { biodiversidade }\end{array}$} & \multirow{3}{*}{84,4} & Redução da vazão & 18,8 \\
\hline & & & Compactação do solo & 68,7 \\
\hline & & & Invasão de flora exótica & 81,3 \\
\hline \multirow[t]{2}{*}{$\begin{array}{l}\text { Extração seletiva } \\
\text { de madeira }\end{array}$} & $\begin{array}{c}\text { Destruição de } \\
\text { habitats naturais }\end{array}$ & 15,6 & \multirow[t]{2}{*}{ Invasão de flora exótica } & \multirow[t]{2}{*}{15,6} \\
\hline & $\begin{array}{c}\text { Perda de } \\
\text { biodiversidade }\end{array}$ & 15,6 & & \\
\hline \multirow[t]{2}{*}{$\begin{array}{l}\text { Despejo de } \\
\text { resíduos }\end{array}$} & \multirow{2}{*}{$\begin{array}{l}\text { Deterioração do valor } \\
\text { estético da paisagem }\end{array}$} & \multirow[t]{2}{*}{68,7} & $\begin{array}{c}\text { Poluição das águas } \\
\text { subterrâneas. }\end{array}$ & 15,6 \\
\hline & & & $\begin{array}{l}\text { Mudança na cor e } \\
\text { odor da água }\end{array}$ & 68,7 \\
\hline \multirow[t]{2}{*}{$\begin{array}{l}\text { Pecuária em área } \\
\text { de nascentes }\end{array}$} & $\begin{array}{l}\text { Deterioração do valor } \\
\text { estético da paisagem }\end{array}$ & 81,3 & \multirow{2}{*}{$\begin{array}{l}\text { Mudança na cor e } \\
\text { odor da água }\end{array}$} & \multirow[t]{2}{*}{68,7} \\
\hline & $\begin{array}{c}\text { Perda de } \\
\text { biodiversidade }\end{array}$ & 81,3 & & \\
\hline \multirow{3}{*}{$\begin{array}{c}\text { Uso das } \\
\text { nascentes } \\
\text { para } \\
\text { dessedentação }\end{array}$} & $\begin{array}{c}\text { Erosão induzida do } \\
\text { solo }\end{array}$ & 43,8 & Assoreamento & 56,3 \\
\hline & Compactação do solo & 68,7 & Redução da vazão & 18,8 \\
\hline & $\begin{array}{c}\text { Contaminação da } \\
\text { água }\end{array}$ & 71,9 & & \\
\hline $\begin{array}{l}\text { Construção de } \\
\text { estruturas de } \\
\text { captação }\end{array}$ & $\begin{array}{l}\text { Deterioração do valor } \\
\text { estético da paisagem }\end{array}$ & 21,9 & $\begin{array}{l}\text { Mudanças na cor e } \\
\text { odor da água }\end{array}$ & 21,9 \\
\hline \multirow[t]{2}{*}{$\begin{array}{l}\text { Agricultura em } \\
\text { área de } \\
\text { nascentes }\end{array}$} & $\begin{array}{c}\text { Contaminação das } \\
\text { águas com } \\
\text { agrotóxicos }\end{array}$ & 15,6 & $\begin{array}{c}\text { Invasão de animais } \\
\text { alheios } \\
\text { ao habitat } \\
\end{array}$ & 15,6 \\
\hline & $\begin{array}{c}\text { Erosão induzida do } \\
\text { solo }\end{array}$ & 12,5 & Assoreamento & 12,5 \\
\hline $\begin{array}{l}\text { Const./Manut. de } \\
\text { estradas na } \\
\text { periferia }\end{array}$ & $\begin{array}{l}\text { Fragmentação dos } \\
\text { corredores ecológicos }\end{array}$ & 25,0 & Assoreamento & 6,3 \\
\hline $\begin{array}{l}\text { Reflorestamento } \\
\text { não planejado }\end{array}$ & $\begin{array}{c}\text { Introdução de flora } \\
\text { exótica em áreas de } \\
\text { nascentes }\end{array}$ & 21,9 & $\begin{array}{c}\text { Alteração das relações } \\
\text { ecossistêmicas }\end{array}$ & 21,9 \\
\hline \multirow{2}{*}{$\begin{array}{l}\text { Construção de } \\
\text { reservatórios para } \\
\text { dessedentação }\end{array}$} & \multirow{2}{*}{$\begin{array}{l}\text { Deterioração do valor } \\
\text { estético da paisagem }\end{array}$} & \multirow[t]{2}{*}{75,0} & $\begin{array}{c}\text { Mudança dos padrões } \\
\text { de drenagem superficial }\end{array}$ & 34,4 \\
\hline & & & Erosão induzida do solo & 6,3 \\
\hline
\end{tabular}

Fonte - Autores (2018)

Note-se que, as principais ações impactantes são o desmatamento, a pecuária em áreas de nascentes, o uso das nascentes para dessedentação e a construção de reservatórios para essa finalidade. Cabe salientar que, de acordo com a classificação de Calheiros (2004), a maioria das nascentes estudadas ( $81,3 \%$ do total) é de fluxo Difuso e as restantes, de fluxo Concentrado (sendo quatro delas com acúmulo inicial de água). 
Os resultados apresentados no Quadro 1 explicam por que, na determinação do Índice de Impacto Ambiental em Nascentes (IIAN) realizada, 24 das nascentes estudadas estão incluídas nas classes Ruim ou Péssima (Figura 2), sendo que as restantes pertencem à classe Razoável (note-se que não existem nascentes nas classes Ótima e Boa).

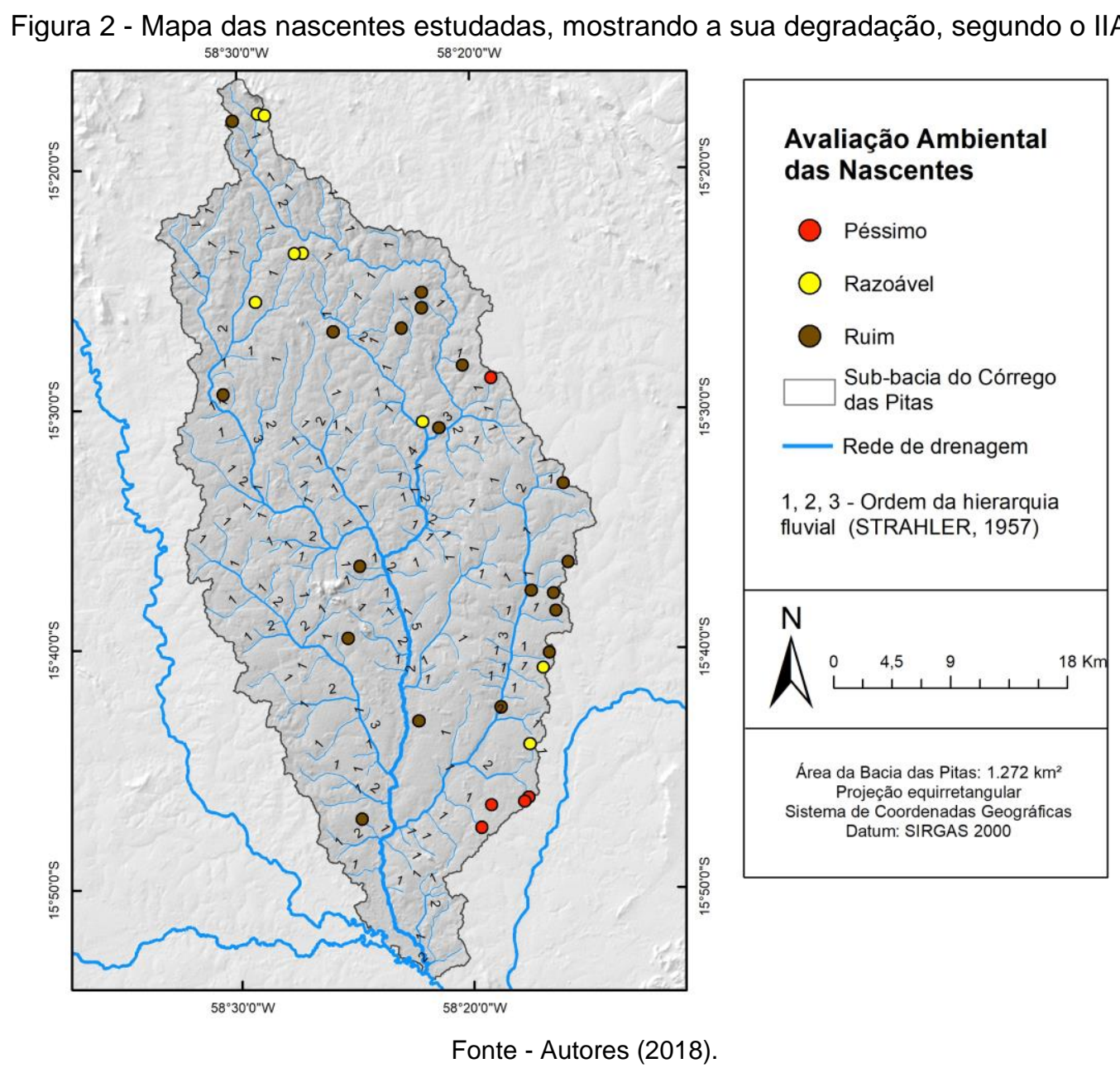

Quando analisada a distribuição das 24 nascentes incluídas nas classes Ruim ou Péssima nos municípios drenados pela sub-bacia, percebe-se que Araputanga lidera com 60,0\% das 15 nascentes estudadas neste município, seguido por São José dos Quatro Marcos $(87,3 \%$ das oito nascentes estudadas) e Gloria do Oeste (com sete das oito nascentes estudadas, ou seja, 87,5\%). Em Indiavaí se localiza apenas uma das 24 nascentes e está incluída na classe Ruim.

As principais causas de degradação identificadas são: substituição da vegetação nativa na periferia das nascentes (associada à invasão da pecuária), ausência de reflorestamento (ou reflorestamento restringido onde tem sido realizado, desrespeitando a legislação vigente e plantando espécies exóticas), uso constante da totalidade das nascentes (acompanhado da construção de reservatórios), falta de proteção (sendo que todas as nascentes estudadas são de fácil acesso) e falta de identificação.

\section{Percepção dos proprietários rurais sobre as nascentes e o seu manejo}

Das 32 áreas de nascentes estudadas, uma está inserida em propriedade pública e as restantes, em 28 propriedades rurais (porque há duas propriedades com mais de uma nascente). Assim, a amostra 
esteve constituída por esses 28 proprietários rurais. A caracterização deles permitiu constatar que 25 deles são homens e apenas três mulheres, possuindo, a maioria ( $75,0 \%$ do total), mais de 60 anos, seguido daqueles com idade entre 51 e 60 anos (10,7\%). Muito poucos deles estão nas faixas etárias de 41-50 e 31-40 anos (apenas 7,1\% do total, em cada uma destas faixas) como mostrado na Figura 3.

Figura 3 - Faixas etárias dos proprietários rurais pesquisados (em anos).

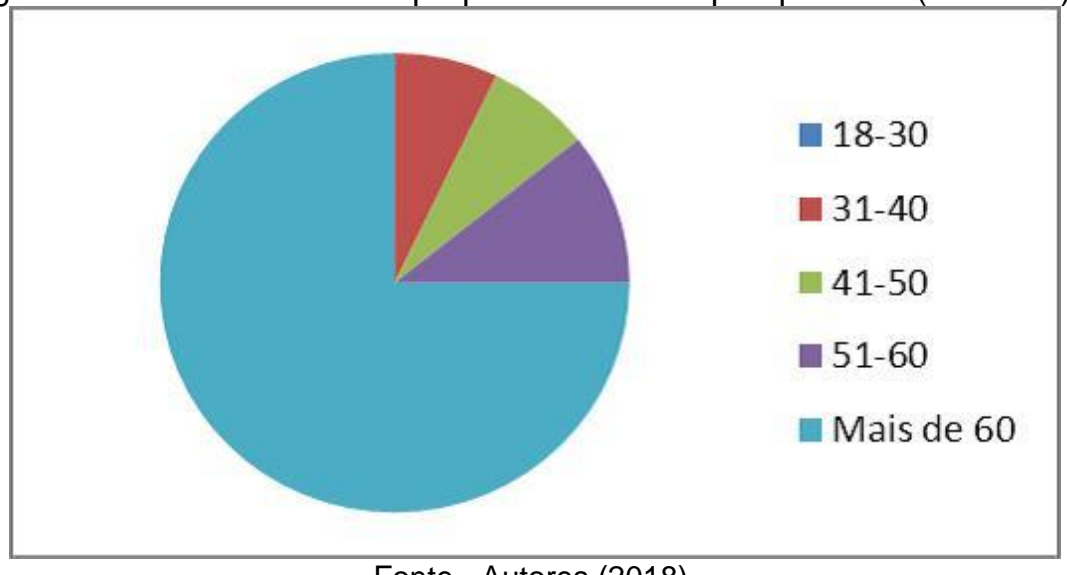

Fonte - Autores (2018).

Em pesquisa semelhante, Gonçalves e Chagas (2017), também constataram que a maioria dos proprietários rurais amostrados eram pessoas com idade acima de 55 anos, o que indica que é cada vez menor a presença de jovens envolvidos nas atividades das propriedades rurais. Vale observar que esse processo de migração dos jovens do campo para a cidade, conhecido como êxodo rural, vem sendo apontado por estudos como o de Peripolli e Zoia (2011). Para Winck et al. (2013) esses jovens abandonam o campo principalmente para tentar se inserir no mercado de trabalho urbano.

Em relação ao grau de escolaridade, apenas um declarou ser analfabeto e outro admitiu ter alcançado o nível superior. Portanto, a maioria (53,6\%) ainda não completou o ensino fundamental I (ou seja, até a $4^{\mathrm{a}}$ série) sendo que com o fundamental II incompleto (de $5^{\mathrm{a}}$ a $8^{\mathrm{a}}$ série), aparecem quatro proprietários e com Ensino Médio não concluído, outros quatro (14,3\% em casa caso, respectivamente). Isto indica que $82,2 \%$ da amostra possui um nível de escolaridade muito baixo (Figura 4).

Figura 4 - Nível de escolaridade dos proprietários rurais.

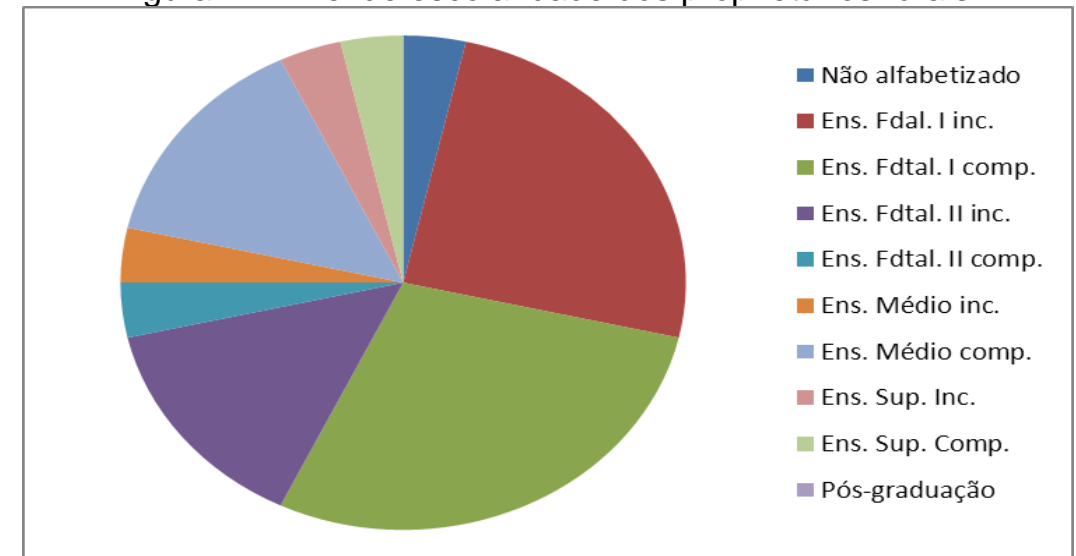

Legenda: Ens.-Ensino; Fdtal-Fundamental; Sup.-Superior; Inc.-Incompleto; Comp.-Completo. Fonte - Autores (2018).

Cabe destacar que esta realidade não se restringe aos proprietários da área de estudo, pois conforme relatam Oliveira et al. (2012), 80\% dos agricultores do semiárido do Estado da Paraíba não 
concluíram o ensino fundamental. Também Mendes et al. (2012), em pesquisa sobre a percepção de proprietários rurais sobre APPs e Reserva Legal no Estado de Santa Catarina, constataram que a maioria tinha apenas o ensino fundamental incompleto.

No caso da pesquisa realizada pelo Instituto Nacional de Colonização e Reforma Agrária (INCRA) sobre Qualidade de Vida, Produção e Renda dos Assentados da Reforma Agrária (envolvendo 804.867 famílias assentadas entre 1985 e 2008, em 1.164 assentamentos distribuídos por todo o Brasil), foi evidenciado que, mesmo com um nível de alfabetização de $84 \%$ dos assentados, apenas $42,88 \%$ possuem até a $4^{a}$ série, revelando-se que o principal problema está no ensino médio e superior, com acesso inferior à 10,0\% (INCRA, 2010). Assim, os dados referentes ao ensino médio e superior apresentados pelo INCRA não diferem muito do encontrado nos proprietários rurais analisados nesta pesquisa, como mostrado na Fig. 04 apresentada anteriormente.

Quanto à participação em cursos profissionalizantes, apenas cinco proprietários fizeram algum tipo de formação, o que evidencia que a maioria não tem tido a oportunidade de aperfeiçoar seus conhecimentos sobre o manejo das atividades rurais. É importante ressaltar que alguns dos cursos realizados não possuem vinculo direto com as atividades rurais (Eletricista e Pintor), enquanto outros sim (Doma de animais, Mecânica de trator e Cooperativismo).

Em relação ao seu estado de origem, apenas três são de Mato Grosso, sendo os restantes, advindos de São Paulo (11 proprietários); Goiás (sete); Minas Gerais (cinco) e Paraná (dois). Essa origem reflete a história de colonização do sudoeste de Mato Grosso, que foi colonizada principalmente por paulistas, goianos e mineiros.

Quando perguntados se vivem exclusivamente da atividade rural, 67,9\% responderam afirmativamente e o restante $32,1 \%$ admitiu possuir, também, outras fontes de renda.

Em relação ao tempo de moradia na propriedade, constatou-se que 19 dos proprietários constituintes da amostra $(67,7 \%$ do total) têm vivido por mais de 20 anos nela, indicando uma percentagem expressiva de famílias que vivem há muitos anos na zona rural.

Considerando que atualmente muitos proprietários rurais moram em cidades, viajando continuamente até a sua propriedade, foi perguntado aos proprietários se residem de forma permanente na propriedade. Neste item, $85,7 \%$ das respostas foram positivas; cabe ressaltar que em uma das propriedades (com duas nascentes) não há moradores permanentes, enquanto em outra (também com duas nascentes) moram três pessoas; portanto, no caso contaram-se duas propriedades e quatro nascentes.

Quando perguntada a quantidade de pessoas que reside na propriedade, confirmou-se que em $53,6 \%$ delas moram apenas uma ou duas pessoas e nas restantes entre três e cinco pessoas; este é outro dado que indica a tendência dos jovens a abandonar o campo para morar em cidades (e o perigo futuro dos pais quando, por causa da idade, ter que vender as suas terras por não ter mão de obra para atendê-las).

Em relação à área da propriedade, foi verificado que apenas três propriedades possuem até 20 hectares; 11 propriedades de 21 a 40 hectares; cinco de 41 a 60 hectares e nove propriedades possuem mais que 60 hectares (Figura 5). Ou seja, $50 \%$ dos proprietários possuem mais de 40 hectares (e dos nove que possuem acima de 60 hectares, dois possuem mais de 80 ).

Figura 5 - Área das propriedades amostradas (em hectares).

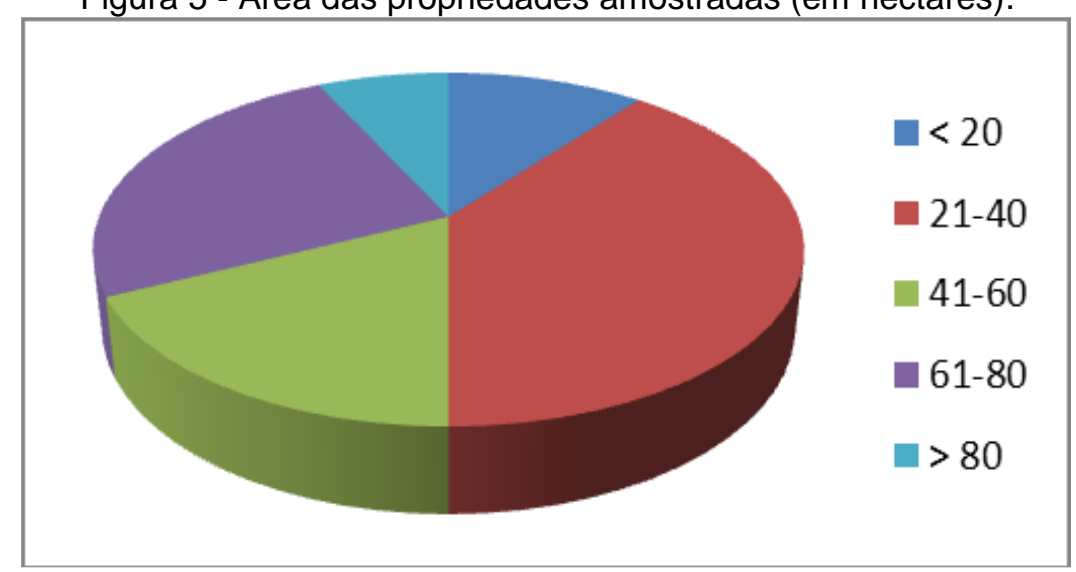

Fonte - Autores (2018). 
Paralelamente observa-se que, de acordo com EMBRAPA (2017), todas as propriedades apresentam menos de um módulo fiscal (80 hectares para os municípios de Araputanga, Gloria D'Oeste e São José dos Quatro Marcos, onde estão inseridas as propriedades da área de estudo). Salienta-se que módulo fiscal é uma unidade de medida estipulada pelo INCRA, cujo valor varia para diferentes municípios conforme a Instrução Normativa № 11, de 04 de abril de 2003.

Em relação ao extrativismo nas propriedades, destacam-se a pecuária e a agricultura, sendo a pecuária (leiteira e de corte) as mais expressivas, pois estão presentes em todas as propriedades. No caso da agricultura, merecem destaque o cultivo de mandioca, milho e cítricos, apesar de contar com outras culturas menos expressivas como banana e cana de açúcar, bem como a criação de suínos, peixes e aves (Tabela 1).

Tabela 1 - Percentuais das principais produções obtidas nas propriedades analisadas

\begin{tabular}{|c|c|c|c|c|c|c|c|c|c|}
\hline \multicolumn{3}{|c|}{ Pecuária } & \multicolumn{4}{c|}{ Agricultura } & \multicolumn{2}{c|}{$\begin{array}{c}\text { Criaçã } \\
\text { o de }\end{array}$} & \multicolumn{2}{c|}{$\begin{array}{c}\text { Plantações } \\
\text { florestais }\end{array}$} \\
\cline { 1 - 1 } & Leixes & Eucalipto & Teca \\
\hline 46,4 & 42,9 & 7,1 & 21,4 & 10,7 & 32,1 & 21,4 & 17,9 & 7,1 & 3,6 \\
\hline
\end{tabular}

Os excedentes desses produtos são comercializados na própria região, salvo a cana de açúcar plantada em cinco propriedades, que é dedicada exclusivamente para alimentação animal, especialmente durante a época da seca.

Outro elemento constatado é que em $67,9 \%$ das propriedades amostradas se utiliza o sistema de criação extensivo e em $28,1 \%$ o semiextensivo, apesar dos impactos ambientais negativos (diretos ou indiretos) que esses sistemas têm provocado nas áreas de nascentes, por causa do desmatamento; a utilização da água das nascentes para dessedentação; o vertimento de resíduos (como fezes de animais) e a construção de reservatórios para dessedentação (ver Quadro 1).

Todavia, estes dados apontam para a necessidade de integrar os sistemas produtivos (por exemplo, a Integração Lavoura-Pecuária-Floresta-ILPF) nessas propriedades menores que um módulo fiscal, reduzindo os impactos ambientais e gerando outros benefícios como a recuperação de pastagens; rotação de culturas; aumento da rentabilidade por hectare e diminuição do risco financeiro (EMBRAPA, 2017). Ao mesmo tempo, como apontado neste documento (EMBRAPA, 2017) poderiam contribuir para a redução das emissões de gases de efeito estufa por conceito de ILPF, que permitiu sequestrar 21,8 milhões de toneladas de $\mathrm{CO}_{2}$ equivalente no Brasil, entre os anos de 2010 e 2015.

Oliveira et al. (2012) chamam a atenção para o fato de que a falta de instrução dos proprietários pode ter contribuído para a não adesão a estes modelos de produção. No caso estudado, como a maioria deles não completou o ensino fundamental e muito poucos realizaram cursos profissionalizantes, isto tem desfavorecido a aquisição de conhecimentos para o uso de técnicas ambientalmente adequadas na realização das atividades na propriedade.

Em relação à utilização de assistência técnica, a maioria da amostra $(60,7 \%)$ respondeu afirmativamente; porém, esta assistência é recebida de forma esporádica, como reconhecido por 15 desses proprietários. Essa assistência é realizada geralmente pelo veterinário $(70,6 \%$ dos que a recebem) em decorrência de a maioria das propriedades estudadas terem como principal atividade, a produção pecuária. Apenas dois deles se auxiliam de um profissional agrônomo.

Como complemento, foi questionado sobre quais as fontes das informações técnicas que utilizam. Nas 24 respostas obtidas (quatro proprietários não quiseram ou não souberam responder) verificouse que elas são obtidas maioritariamente através da TV, seguida do rádio, das conversas com os vizinhos e da internet. Com pouca expressividade aparecem outras fontes de informações como 
revistas de conteúdo geral, jornais impressos e revistas técnicas, o que pode estar relacionado ao baixo grau de escolaridade da população pesquisada.

O bloco II do questionário aplicado foi concebido para questões referentes às nascentes existentes nas propriedades amostradas. Na primeira questão perguntavam-se quais os tipos de fontes de água existentes na propriedade, constatando-se que, além da totalidade possuir nascentes (em 17 delas associadas a córregos), em 22 propriedades o córrego ou as nascentes foram represados para dessedentação de animais e, além dessas fontes, outras 21 propriedades possuem poços rasos. Esses poços abastecem a água para consumo humano em 19 propriedades (67,9\% do total), enquanto nas restantes a água para os humanos beberem procede das nascentes.

A segunda questão buscava conhecer os tipos de utilização da água das nascentes. As respostas mostraram uma diversidade de usos (Tabela 2):

Tabela 2 - Usos da água das nascentes nas propriedades pesquisadas.

\begin{tabular}{|l|c|c|}
\hline \multicolumn{1}{|c|}{ Finalidade } & N. de propriedades & $\%$ \\
\hline Para beber & 09 & 32,1 \\
\hline Para os trabalhos domésticos & 07 & 25,0 \\
\hline Para irrigação & 07 & 25,0 \\
\hline Para dessedentar animais & 28 & 100 \\
\hline
\end{tabular}

Fonte - Autores (2018).

Em relação à qualidade da água das nascentes, todos os proprietários amostrados consideram que é Ótima $(60,7 \%)$ ou Boa $(39,3 \%)$ mesmo que, para a sua utilização nas residências, tenham sido construídas estruturas de captação da água das nascentes, onde a presença de algas gera mudanças na cor e odor da água (impacto ambiental indireto desta atividade humana).

Tanto os diversos tipos de utilização constatados da água das nascentes como as opiniões sobre a qualidade da sua água, podem explicar o porquê $100 \%$ das pessoas amostradas opina que as nascentes devem ser preservadas, argumentando diversas razões, que podem ser agrupadas da seguinte forma (Figura 6).

Figura 6 - Motivos para preservar as nascentes, segundo os proprietários rurais.

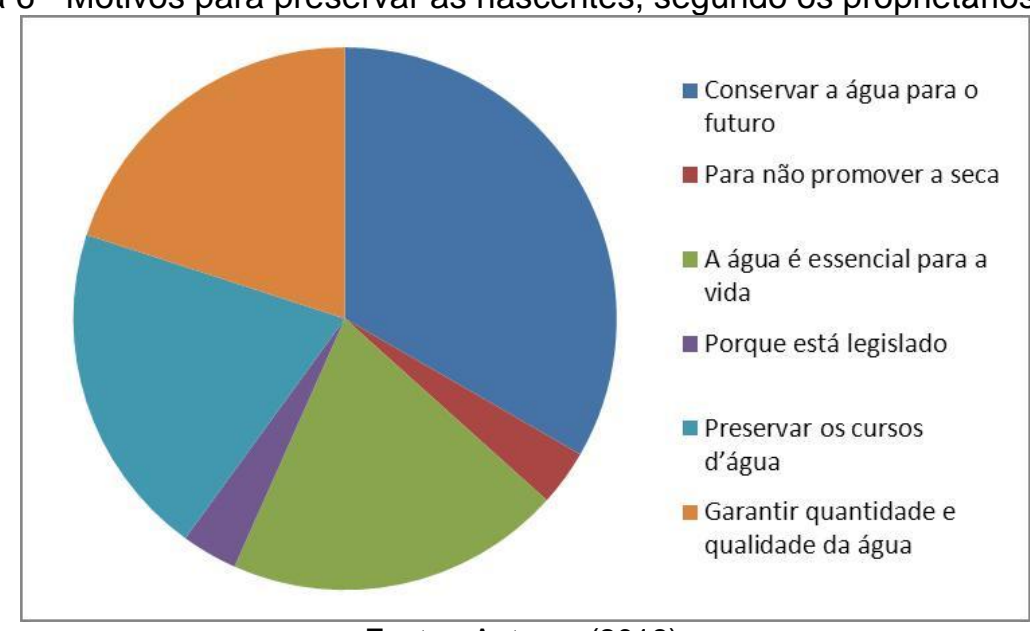

Fonte - Autores (2018).

Nota-se que as principais razões colocadas são: o perigo de a água acabar no futuro; que a água das nascentes é vital para o planeta (e para garantir a sua sobrevivência e a dos animais); que as nascentes permitem preservar os cursos d'água, e que proteger as nascentes garante a qualidade e 
quantidade de água (evitando impactos como a compactação do solo advinda do pisoteio do gado, e o assoreamento).

Estes resultados coincidem com os obtidos por autores como Souzaet al. (2015) e Prudente et al. (2014) em pesquisas realizadas com proprietários rurais do município de Castilho e da região de Bauru (SP), respectivamente. Porém, se contradizem com as ações que os proprietários pesquisados têm executado nas nascentes, gerando diversos impactos ambientais (ver Quadro 1) o que poderia ser explicado pela falta de conhecimentos técnicos para o manejo das propriedades e a falta de instrução dos proprietários pesquisados, como evidenciam os resultados do bloco I do questionário aplicado (explicados acima).

Outra das questões deste bloco estava relacionada com a largura da faixa de vegetação que preserva as margens das nascentes nas propriedades. Nas respostas, 39,3\% dos proprietários admitiram não possuir faixa de vegetação. Nos restantes casos, essa largura é variada: até 15 metros em cinco propriedades (17,0\%); entre 15 e 50 metros em outras sete $(25,0 \%)$ e de mais de 50 metros nas restantes cinco $(17,0 \%)$. Esta realidade é preocupante, uma vez que, segundo a legislação vigente, a faixa deve ser de $15 \mathrm{~m}$. no caso das propriedades estudadas, que possuem menos de 04 módulos fiscais.

Na questão seguinte perguntou-se aos proprietários de quem é a responsabilidade pela preservação das nascentes. Nas 27 respostas válidas, a grande maioria deles $(85,7 \%)$ reconheceu que é sua (por ser o proprietário da terra da nascente), seja de maneira única, ou em corresponsabilidade com a comunidade local (cinco respostas), com o governo federal (três respostas), com a Prefeitura municipal, ou o governo do Estado (duas respostas em cada caso).

Quando questionados se aplicam alguma medida de proteção para as nascentes na propriedade, das 26 respostas válidas, quase a metade $(42,3 \%)$ admitiu que não protege as suas nascentes. Ou seja, dos 15 proprietários que aplicam alguma proteção, a maioria utiliza cercas (12 casos), às vezes acompanhada do reflorestamento com espécies nativas (nove casos), especialmente Buriti (Mauritia flexuosa; Mauritia vinífera Mart.). Mais uma vez estes resultados chamam a atenção quando comparados com os impactos ambientais que os proprietários têm gerado (e com o fato deles terem admitido serem os principais responsáveis pela preservação das nascentes) (ver Quadro 1).

Também foi perguntado aos proprietários se observaram alguma alteração na qualidade da água nos últimos anos, sendo que para 50\% deles não tem ocorrido alteração (17,9\% admitiram alterações, sem especificar quais, e um significativo $32,1 \%$ não quiseram ou não souberam responder). Em relação ao volume de água das nascentes, as respostas também foram diversas como mostrado no Tabela 3.

Tabela 3 - Variações percebidas sobre o volume de água das nascentes.

\begin{tabular}{|l|l|l|}
\hline Percepções & Quant. De respostas & $\%$ do total \\
\hline Manteve-se estável & 11 & 39,3 \\
\hline Aumentou & 10 & 35,7 \\
\hline Diminuiu & 06 & 21,4 \\
\hline Não soube ou não quis responder & 01 & 3,6 \\
\hline
\end{tabular}

Fonte - Autores (2018).

Note-se que há percepção sobre os efeitos de ações como o desmatamento de áreas de nascentes, a utilização da sua água para dessedentação de animais e a construção de reservatórios, na geração 
de impactos ambientais indiretos como o assoreamento de nascentes e a redução da sua vazão (ver Quadro 1).

As últimas questões deste bloco estavam relacionadas com o tratamento da água utilizada para consumo humano nas propriedades. Neste sentido, foi questionado inicialmente se os proprietários tratam a água de consumo, corroborando-se que apenas nove deles $(31,1 \%$ da amostra) aplicam algum tipo de tratamento, especialmente a Filtração (realizada em seis desses imóveis rurais), a Desinfecção (em outros três imóveis). Quase todas essas pessoas realizam a manutenção periódica do sistema de tratamento; porém, sem periodicidade definida.

Finalmente foi questionado se eles consideram o tratamento eficiente, resultando que, dos sete proprietários que disseram ter avaliado a eficiência, 100\% considera que o tratamento é eficiente.

O último bloco de questões contidas no instrumento de coleta de dados (bloco 3) estava dedicado às práticas de manejo utilizadas na propriedade, tendo em vista a sua influência na degradação das nascentes. No primeiro quesito buscou-se saber se os proprietários realizam a aragem das suas terras e qual é o método utilizado.

Verificou-se que, das 26 respostas válidas, em três propriedades a aragem não é realizada, enquanto que em outras 22 propriedades (95,7\%) o dono faz a aragem das terras utilizando trator, e apenas em uma $(4,3 \%)$ utiliza-se o cavalo. Na amostra pesquisada não se pratica a aragem com bois.

Tendo em vista que todos os proprietários que praticam a aragem geram algum tipo de restos de culturas, a segunda questão visava conhecer o destino que eles dão a esses restos na propriedade. Nas respostas, mesmo que diversas, a grande maioria (23 respostas, representando $82,1 \%$ do total) admitiu que deixa esses restos no campo para que se incorporem ao solo; a seguir aparecem aqueles que utilizam os restos para a alimentação dos animais, ou os queimam (duas respostas em cada caso, ou seja, $7,1 \%$ do total, respectivamente) e apenas em uma propriedade esses restos são utilizados para fazer compostagem.

Tanto a aragem das terras quanto o próprio desmatamento inicial delas, induzem processos erosivos (ou os aceleram quando já existiam). Por isso na seguinte questão perguntou-se ao proprietário se possui áreas de erosão na propriedade, sendo que a maioria deles não reconhece a existência de tais áreas (18 respostas, que representam $64,3 \%$ do total) e somente 10 admitiram a existência desse problema ( $35,7 \%$ da amostra).

Para estes últimos, as possíveis causas dessa erosão são a falta de vegetação advinda do desmatamento (quatro respostas), em associação com a declividade do terreno desmatado (três respostas) a ação da chuva em áreas onde foram usadas máquinas agrícolas, como trator, esteira e retroescavadeira (duas respostas), o pisoteio do gado, com formação de sulcos (duas respostas). Chama a atenção o fato de que apenas um dos proprietários pesquisados reconhece a falta de curvas de nível como possível causa da erosão, conformando o antes explicitado no sentido de que a baixa preparação deles contribui para o uso de práticas agrícolas que degradam o meio ambiente.

Esta conclusão é sustentada, também, no fato de que dos 10 proprietários que reconheceram possuir áreas de erosão, apenas cinco deles implementaram alguma medida para recuperar ou controlar esse processo, particularmente a construção de barragens, a criação de barreiras (de madeira, galhos de árvores e folhas de bacurizeiro) ou a plantação de grama.

Cabe destacar que, neste quesito, existe correspondência nas respostas com o levantamento dos impactos ambientais negativos das atividades realizadas nas propriedades rurais e suas consequências para a dinâmica das nascentes, mostrado no Quadro 1. Também foi questionado se eles utilizam a prática de queimadas na propriedade, resultando que todos os entrevistados responderam negativamente.

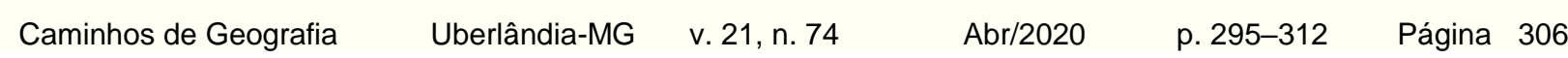


Finalmente, no questionário colocou-se a questão relacionada com os problemas ambientais que mais afetam às nascentes, na opinião dos proprietários. Nas respostas obtidas, três proprietários $(10,7 \%$ da amostra) não identificaram problemas ambientais, enquanto outros 25 identificaram a destruição da mata ciliar como problema principal (18 respostas, representando $64,3 \%$ do total da amostra), seguido pela compactação do solo advinda do pisoteio do gado (admitido por 16 proprietários, ou seja, $57,1 \%$ do total) e o assoreamento das nascentes, com oito respostas $(28,6 \%)$ (Figura 7).

Figura 7 - Principais problemas ambientais identificados pelos proprietários.

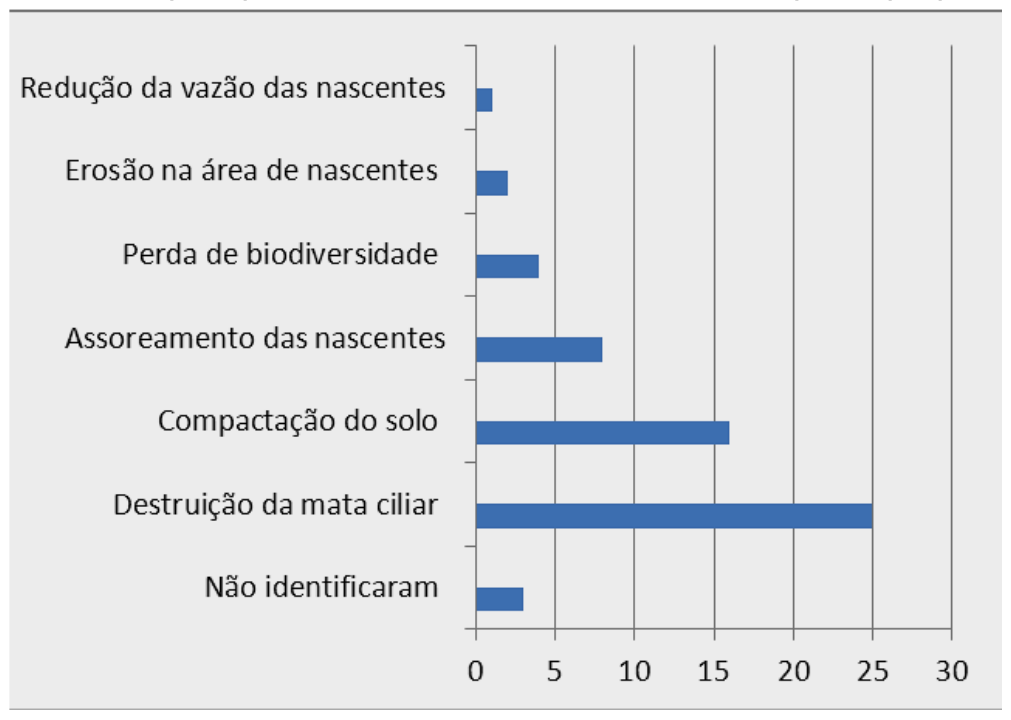

Fonte - Autores (2018).

Uma importância menor foi concedida à perda de biodiversidade (14,3\% das respostas), à erosão na área de nascentes (7,1\% das respostas) e à diminuição do fluxo de água das nascentes (apenas um proprietário, ou seja, $3,6 \%$ do total). Percebe-se que os proprietários identificam apenas cinco dos 23 impactos ambientais (11 diretos e 12 indiretos), advindos das suas atividades nas propriedades. Paralelamente, mesmo que declaram a destruição da mata ciliar (desmatamento) como um problema (impacto) e não como a causa da maioria dos impactos relacionados por eles.

\section{Ações prioritárias para uma adequada gestão ambiental das nascentes estudadas}

Com base nos resultados apresentados, bem como na legislação brasileira vigente no nível federal sobre o tema e as possibilidades que oferecem as estruturas institucionais e da sociedade civil nos municípios que abrangem a sub-bacia do córrego das Pitas, foi elaborada uma proposta de ações cuja implementação se considera prioritária para subsidiar uma adequada gestão ambiental das nascentes estudadas (Quadro 2). Ressalta-se que essas ações deverão ser implementadas através do Comité de Bacia Hidrográfica do rio Jauru, do qual forma parte o córrego das Pitas (podendo ser estendidas a outras sub-bacias com similar problemática nas suas nascentes).

Note-se que, para cada ação, aparecem os principais atores sociais locais envolvidos na sua implementação. Cabe salientar, também, que uma parte significativa dessas ações poderia formar parte de um futuro projeto de extensão, concebido pelas instituições universitárias presentes nos municípios, como a Universidade do Estado de Mato Grosso (UNEMAT) e a Faculdade Católica de Araputanga (FCARP), em parceria com o Comité de Bacia Hidrográfica do rio Jauru. 
Quadro 2 - Ações prioritárias de gestão ambiental nas nascentes estudadas.

\begin{tabular}{|c|c|c|}
\hline Ações prioritárias & $\begin{array}{l}\text { Atores envolvidos nos } \\
\text { municípios }\end{array}$ & $\begin{array}{l}\text { Base legal } \\
\text { (leis federais) }\end{array}$ \\
\hline $\begin{array}{l}\text { 1- Criar um programa de Educação Ambiental nas escolas } \\
\text { orientado à formação de capacidades em gestão de } \\
\text { recursos hídricos e nascentes, utilizando os resultados } \\
\text { desta pesquisa na produção do material educativo. }\end{array}$ & $\begin{array}{l}\text { Secretarias de Educ., } \\
\text { Esporte e Lazer }\end{array}$ & $\begin{array}{l}6.938 / 1981 \\
9.795 / 1999\end{array}$ \\
\hline $\begin{array}{l}\text { 2- Criar a Agenda } 21 \text { nas escolas, utilizando os resultados } \\
\text { desta pesquisa no estabelecimento das suas metas e } \\
\text { objetivos. }\end{array}$ & $\begin{array}{l}\text { Escolas de Educação } \\
\text { Básica } \\
\text { Secretarias de Educ., } \\
\text { Esporte e Lazer. }\end{array}$ & $9.795 / 1999$ \\
\hline $\begin{array}{l}\text { 3- Fomentar a criação de viveiros escolares para apoiar o } \\
\text { reflorestamento das nascentes degradadas na sub-bacia } \\
\text { do córrego das Pitas. }\end{array}$ & $\begin{array}{c}\text { Escolas de Educação } \\
\text { Básica } \\
\text { Prefeituras } \\
\text { Sindicatos rurais }\end{array}$ & $\begin{array}{c}6.938 / 1981 \\
9.795 / 1999 \\
12.651 / 2012 \\
12.727 / 2012 \\
\end{array}$ \\
\hline $\begin{array}{l}\text { 4- Estabelecer Dias de Campo (em datas alegóricas) nas } \\
\text { escolas dos municípios da sub-bacia do córrego das Pitas, } \\
\text { para o plantio de mudas nas nascentes degradadas. }\end{array}$ & $\begin{array}{l}\text { Escolas de Educação } \\
\text { Básica; IES; Sindicatos } \\
\text { rurais. }\end{array}$ & $\begin{array}{l}6.938 / 1981 \\
9.795 / 1999\end{array}$ \\
\hline $\begin{array}{l}\text { 5- Utilizar um percentual de plantas nativas medicinais no } \\
\text { reflorestamento das nascentes degradadas }\end{array}$ & $\begin{array}{l}\text { Parceria entre Prefeituras, } \\
\text { Sindicatos Rurais e } \\
\text { EMPAER. }\end{array}$ & $6.938 / 1981$ \\
\hline $\begin{array}{l}\text { 6- Divulgar os resultados desta pesquisa entre as } \\
\text { instituições de ensino da região para a sua utilização em } \\
\text { projetos de extensão orientados à gestão integrada de } \\
\text { recursos hídricos (com ênfase no manejo adequado de } \\
\text { APPs e recuperação de nascentes degradadas). }\end{array}$ & $\begin{array}{l}\text { Escolas de Educação } \\
\text { Básica; } \\
\text { IES. }\end{array}$ & $\begin{array}{c}6.938 / 1981 \\
9.795 / 1999 \\
10.861 / 2004 \\
12.188 / 2010\end{array}$ \\
\hline $\begin{array}{l}\text { 7- Efetivar a criação do Comitê intermunicipal da sub-bacia } \\
\text { hidrográfica das Pitas. }\end{array}$ & $\begin{array}{l}\text { Secretarias de Meio } \\
\text { Ambiente. }\end{array}$ & $\begin{array}{c}6.938 / 1981 \\
9.795 / 1999 \\
12.651 / 2012 \\
12.727 / 2012 \\
\end{array}$ \\
\hline $\begin{array}{l}\text { 8- Criar um banco de dados com a catalogação das } \\
\text { nascentes por município da sub-bacia (contendo } \\
\text { informações como: localização, características, nível de } \\
\text { degradação e proteção), e inseri-lo nos cadastros } \\
\text { territoriais (rural e urbano). }\end{array}$ & $\begin{array}{l}\text { Secretarias de Meio } \\
\text { Ambiente }\end{array}$ & $6.938 / 1981$ \\
\hline $\begin{array}{l}\text { 9- Elaborar um programa de recuperação de nascentes } \\
\text { para a sub-bacia hidrográfica do córrego das Pitas, em } \\
\text { parceria com instituições de ensino, EMPAER, Sindicatos } \\
\text { rurais e Associações de bairros. }\end{array}$ & $\begin{array}{l}\text { Secretarias de Meio } \\
\text { Ambiente e de } \\
\text { Agricultura }\end{array}$ & $\begin{array}{c}6.938 / 1981 \\
10.861 / 2004\end{array}$ \\
\hline $\begin{array}{l}\text { 10- Efetivar, nas propriedades rurais que implementaram } \\
\text { medidas de proteção para as suas nascentes, o } \\
\text { pagamento por serviços ambientais (protetor-recebedor). }\end{array}$ & $\begin{array}{l}\text { Secretarias de Meio } \\
\text { Ambiente. }\end{array}$ & $\begin{array}{l}6.938 / 1981 \\
9.795 / 1999 \\
12.651 / 2012 \\
12.727 / 2012 \\
\end{array}$ \\
\hline $\begin{array}{l}\text { 11- Estabelecer um programa de capacitação dos } \\
\text { proprietários rurais sobre proteção de recursos hídricos e } \\
\text { revitalização de nascentes, com apoio de profissionais das } \\
\text { Prefeituras, IES, EMPAER e outros profissionais técnicos. }\end{array}$ & $\begin{array}{l}\text { Proprietários Rurais } \\
\text { Sindicatos rurais }\end{array}$ & $\begin{array}{c}8.171 / 1991 \\
9.795 / 1999 \\
12.651 / 2012 \\
12.727 / 2012\end{array}$ \\
\hline $\begin{array}{l}\text { 12- Generalizar o reflorestamento e a proteção das } \\
\text { nascentes pelos proprietários, com base na assistência e } \\
\text { acompanhamento técnico, ofertados pelos órgãos } \\
\text { competentes. }\end{array}$ & $\begin{array}{l}\text { Proprietários Rurais; } \\
\text { EMPAER e } \\
\text { Sindicatos rurais }\end{array}$ & $6938 / 1981$ \\
\hline $\begin{array}{l}\text { 13- Sensibilizar aos proprietários sobre a necessidade de } \\
\text { realizar exames laboratoriais da água de nascentes } \\
\text { utilizadas para o consumo humano. }\end{array}$ & $\begin{array}{l}\text { Departamentos de Água e } \\
\text { Esgoto } \\
\text { Secretarias de Saúde }\end{array}$ & $\begin{array}{l}6.938 / 1981 \\
9.795 / 1999\end{array}$ \\
\hline $\begin{array}{l}\text { 14- Instigar a participação das pastorais e/ou ministérios, } \\
\text { por meio de suas lideranças comunitárias, na proteção e a } \\
\text { revitalização de nascentes. }\end{array}$ & Entidades Religiosas & $9.795 / 1999$ \\
\hline $\begin{array}{l}\text { 15- Realizar mutirões com ações voltadas à proteção de } \\
\text { recursos hídricos e recuperação de áreas degradadas, } \\
\text { especialmente as nascentes de zonas urbanas. }\end{array}$ & Associações de bairros & $\begin{array}{l}6.938 / 1981 \\
9.795 / 1999\end{array}$ \\
\hline $\begin{array}{l}\text { 16- Incorporar, na programação permanente, informações } \\
\text { sobre boas práticas na proteção dos recursos hídricos e as } \\
\text { nascentes em particular. }\end{array}$ & Mídias locais & $6.938 / 1981$ \\
\hline $\begin{array}{l}\text { 17- Incorporar os resultados desta pesquisa na } \\
\text { capacitação dos trabalhadores em Educação Ambiental. }\end{array}$ & Empresas locais & $9.795 / 1999$ \\
\hline $\begin{array}{l}\text { 18- Promover a sensibilização dos moradores de áreas de } \\
\text { risco sobre as doenças de veiculação hídrica, associadas } \\
\text { à falta de preservação e revitalização dos corpos hídricos, } \\
\text { através de encontros com os agentes de saúde e } \\
\text { vigilância sanitária dos municípios da sub-bacia. }\end{array}$ & $\begin{array}{l}\text { Secretarias de Saúde } \\
\text { Associações de bairros }\end{array}$ & $9.795 / 1999$ \\
\hline
\end{tabular}

Fonte - Autores (2018).

$\begin{array}{lllll}\text { Caminhos de Geografia } & \text { Uberlândia-MG } & \text { v. 21, n. } 74 & \text { Abr/2020 } & \text { p. 295-312 Página } 308\end{array}$


Assim, as ações apresentadas poderão contribuir para a mitigação dos problemas identificados in loco nas pequenas propriedades rurais estudadas, somando esforços entre as instâncias governamentais, o setor produtivo e a sociedade civil (MATO GROSSO, 2012). Por exemplo, os atores mais expressivos no município de Araputanga (onde se localizam as cabeceiras do córrego das Pitas) e em São José dos Quatro Marcos (médio curso), são os professores e alunos da educação básica e as entidades religiosas.

No primeiro caso, Araputanga possui oito escolas e São José dos Quatro Marcos, 11; esse fato favorece a criação de um programa de educação ambiental no âmbito escolar, orientado à formação e capacitação dos profissionais da educação em gestão de recursos hídricos e nascentes, em particular. Esse programa forneceria suportes teóricos e práticos para desenvolverem a temática com os alunos e incentivá-los ao fortalecimento de hábitos ambientalmente adequados.

Também, estimularia a criação de uma Agenda 21 com metas, objetivos e ações (como a criação de viveiros de mudas com espécies nativas e medicinais para o reflorestamento das nascentes e áreas degradadas, e estabelecimento de Dias de Campo para o plantio nas referidas áreas), estimulando a mudança de mentalidade e comportamentos da comunidade escolar.

No caso da proposta que envolve atores das entidades religiosas (Araputanga possui 40 e São José dos Quatro Marcos, 32, segundo o Censo do Instituto Brasileiro de Geografia e Estatística-IBGE, 2000, ela baseia-se na premissa de que as igrejas possuem grande influência na vida dos seguidores e "...continua sendo a instituição mais confiável para a maioria dos latino-americanos (72\%), seguido da televisão com 49\%...", como afirmara Azevedo (2004, p. 113).

Esses dados permitem orientar ações nas entidades religiosas, conforme a faixa etária dos seguidores, a partir da busca de alianças com estas entidades (através de parcerias com suas lideranças comunitárias) para a sua efetiva participação, por meio de suas pastorais e/ou ministérios, na proteção do meio ambiente em geral e a revitalização de nascentes em particular.

Assim, as ações propostas poderão se implementar através de uma formação em educação ambiental orientada às lideranças, buscando aprofundar na sensibilização dos fieis sobre a conservação do ambiente no momento das pregações e estimulá-los a participar nos trabalhos de mutirões nas propriedades daqueles fiéis onde as nascentes se encontram degradadas.

\section{CONSIDERAÇÕES FINAIS}

A influência constatada das ações antrópicas advindas da ocupação da sub-bacia hidrográfica do córrego das Pitas na geração de diversos impactos ambientais, bem como os resultados do estudo de percepção ambiental dos proprietários em relação com as suas nascentes, indicaram a necessidade de propor, com base na legislação vigente, ações prioritárias orientadas a estimular uma adequada gestão ambiental nas propriedades rurais, envolvendo os atores sociais que poderiam protagonizar a sua implementação.

Para implementar estas ações será preciso desenvolver, em parceria com as instituições de ensino superior presentes nos municípios e os órgãos públicos correspondentes, projetos de pesquisa e de extensão sobre o tema das nascentes que permitam aprofundar o conhecimento sobre o seu nível de degradação e estimular a recuperação das suas condições ambientais.

Recomenda-se que os resultados desta pesquisa sejam amplamente divulgados nos municípios da sub-bacia hidrográfica do córrego das Pitas, tanto no âmbito das prefeituras municipais, como no interior das instituições da sociedade civil. Recomenda-se, também, realizar este tipo de estudos em outras sub-bacias hidrográficas da região onde o histórico da ocupação humana é similar e, portanto, a situação ambiental das nascentes poderia ser parecida à encontrada no caso do córrego das Pitas.

\section{REFERENCIAS}

AMERICO, J. H. P.; CARVALHO, S. L. de.; GONZAGA, M. de L.; LIMA, E. A. C. F.; ARAÚJO, C. A. M. Condições ambientais de propriedades agrícolas e percepção ambiental de produtores rurais do município de Dobrada-São Paulo, Brasil. HOLOS Environment, Rio Claro, v. 12, n. 2, 2012, p. 241. ISSN 15198634 (ON LINE). https://doi.org/10.14295/holos.v12i2.5361

$\begin{array}{llllll}\text { Caminhos de Geografia } & \text { Uberlândia-MG } & \text { v. 21, n. } 74 & \text { Abr/2020 } & \text { p. 295-312 } & \text { Página } 309\end{array}$


AZEVEDO, A. A Igreja Católica e seu papel político no Brasil. Revista Estudos Avançados. São Paulo, vol. 18, no 52, Set./Dec. 2004. https://doi.org/10.1590/S0103-40142004000300009

CABANELAS, I. T. D.; MOREIRA, L. M. A. Estudo sobre o estado de preservação das nascentes do rio Sapato, Lauro de Freitas-BA. Revista de Ciências Médicas e Biológicas, Salvador, 6(2), 2007, p. 160-162. https://doi.org/10.9771/cmbio.v6i2.4192

CALHEIROS, R. O. Preservação e Recuperação das Nascentes. Piracicaba: Comitê das Bacias Hidrográficas dos Rios PCJ - CTRN, 2004, 40 p.

CARDOZO, M. Percepção de riscos ambientais de trabalhadores catadores de materiais recicláveis em um aterro controlado do município de Duque de Caxias/RJ. Dissertação (Mestrado em Saúde Pública e Meio Ambiente). Escola Nacional de Saúde Pública Sérgio Arouca, Rio de Janeiro, 2009. Disponível em: https://bvssp.icict.fiocruz.br/pdf/25905 cardozomm.pdf Acesso em: 24 de setembro 2017.

CHAVES, H. M. L.; SANTOS, L. B. dos. Ocupação do solo, fragmentação da paisagem e qualidade da água em uma pequena bacia hidrográfica. Revista Brasileira de Engenharia Agrícola e Ambiental, Campina Grande, v.13, (Suplemento), p. 922-930, 2009. https://doi.org/10.1590/S1415$\underline{43662009000700015}$

COVRE, E. B. Caracterização de nascentes, cursos d'água e APP's em micro bacia urbana. Estudo de caso do Córrego Baú em Cuiabá-MT. Brasil. Dissertação (Mestrado em Recursos Hídricos) 2010. Disponível em: http://livros01.livrosgratis.com.br/cp147829.pdf Acesso em: 23 de agosto 2017.

DAY, R. H. Psicologia da Percepção. Rio de Janeiro: José Olympio Editora, 1979.

DIEGUES, A. C. Etnoconservação da natureza: enfoques alternativos. In: DIEGUES, A. C. (Org.), Etnoconservação: novos rumos para a proteção da natureza nos trópicos. São Paulo:

Annablume/Hucitec, 2000, p. 1-46.

EMBRAPA - Empresa Brasileira de Pesquisa Agropecuária. ILPF em Números. REGIÃO 2: MT, GO e DF. Biblioteca Embrapa Agrossilvipastoril. 2017. Disponível em:

https://ainfo.cnptia.embrapa.br/digital/bitstream/item/157581/1/2017-cpamt-ilpf-em-numeros-reginal2.pdf Acesso em: 28 de agosto 2018.

FERRONATO, M. L. Percepção ambiental coletiva e envolvimento de agricultores familiares em ações de recuperação de áreas degradadas na zona da mata rondoniense. Dissertação (Mestrado em Ciências Ambientais). Universidade Federal de Rondônia, 2016, 68 p. Disponível em: http://ecopore.org.br/wp-content/uploads/2016/11/Disserta\%C3\%A7\%C3\%A3o-Marcelo-LucianFerronato1.pdf Acesso em: 21 de agosto 2017.

FILGUEIRA, H. J. A.; SILVA, T. C. da.; LIMEIRA, M. C. M., SILVA, M. R. M.; SILVA, A. L. da. Usos e usuários de água de nascentes do alto curso da bacia hidrográfica do rio Gramame, Paraíba. $X$ Simpósio de Recursos Hídricos do Nordeste, 2010 Anais [...], Fortaleza, CE. Disponível em: http://www.acquacon.com.br/xsrhn/data.php Acesso em: 13 de junho 2017.

GONÇALVES, M. da P. M.; CHAGAS, A. O. V. das. Restauração de áreas na percepção de proprietários rurais do entorno da reserva serra das almas. Revista Polêmica. Universidade do Estado de Rio de Janeiro-RJ, vol. 17 n. 1, 2017. https://doi.org/10.12957/polemica.2017.28297

IBGE-Instituto Brasileiro de Geografia e Estatística. Censo demográfico 2000. Disponível em: https://ww2.ibge.gov.br/home/estatistica/populacao/censo2000/populacao/censo2000 populacao.pdf Acesso em: 01 de abril 2019.

INCRA - Instituto Nacional de Reforma Agrária. Pesquisa Sobre a Qualidade de Vida, Produção e Renda dos Assentamentos da Reforma Agrária. Apresentação dos Primeiros Resultados. Ministério do Desenvolvimento Agrário. Brasília, 2010. Disponível em: http://www.incra.gov.br/sites/default/files/uploads/reforma-agraria/questao-agraria/reformaagraria/pgra - apresentao.pdf Acesso em: 21 de outubro 2017.

JODELET, D. Representações sociais: um domínio em expansão. In: JODELET, D. (Org.) As representações sociais. Rio de Janeiro: EDUERJ. 2001.

LENCIONI, S. Região e Geografia. São Paulo: EDUSP, 2003. 
MACEDO, R. L. G. Percepção, conscientização e conservação ambientais. Lavras: FAEPE, 2005.

MAGALHÃES JUNIOR, A. P. A situação do monitoramento das águas no Brasil - Instituições e iniciativas. Revista Brasileira de Recursos Hídricos. Porto Alegre-RS, vol. 5, n. 3: 113-115, 2000. https://doi.org/10.21168/rbrh.v5n3.p113-135

MARCOMIN, F. E.; SATO, M. Percepção, paisagem e Educação Ambiental: uma investigação na região litorânea de Laguna-SC, Brasil. Educação em Revista. Belo Horizonte, v. 32, n. 02, p. 159186 Abril-Junho 2016. Disponível em: http://www.scielo.br/pdf/edur/v32n2/1982-6621-edur-32-0200159.pdf Acesso em: 10 de abril 2018. https://doi.org/10.1590/0102-4698125694

MARIN, A. A.; TORRES, O. H.; COMAR, V. A educação ambiental num contexto de complexidade do campo teórico da percepção. Interciência, Santiago, Chile, 28(10): 616-619, 2003. Disponível em: http://ve.scielo.org/scielo.php?script=sci arttext\&pid=S0378-18442003001000012 Acesso em: 12 de julho 2017.

MARIA, J. A.; CAVALCANTI, I.; EIRÓ, F. H. Percepção ambiental e mudanças climáticas. In: Encontro da Sociedade Brasileira de Economia Ecológica, 9, 2011, Brasília. Anais [...] Brasília, 2011. Disponível em: http://www.ecoeco.org.br/ conteudo/publicacoes/encontros/ix en/GT3-162-9120110613132907.pdf Acesso em: 08 de junho 2017.

MAROSTEGA, G. B. Características físicas, ocupação territorial, atividades econômicas e indicadores hidrológicos da bacia hidrográfica do rio Jauru - MT. Dissertação (Ciências Ambientais). Universidade do Estado de Mato Grosso, Cáceres-MT, Brasil, 2012, 114 p.

MAROTI, P. S.; SANTOS, J. E.; PIRES, J. S. R. Percepção ambiental de uma Unidade de Conservação por docentes do ensino fundamental. In: SANTOS, J. E.; PIRES, J. S. R. (eds.) Estação Ecológica de Jataí. São Carlos: RiMa, 2000.

MATO GROSSO (Estado). Secretaria de Estado de Educação. Orientações Curriculares: Diversidades Educacionais. Secretaria de Estado de Educação de Mato Grosso. Cuiabá: Gráfica Print, 2012.

MENEZES, F. de. Percepção dos produtores rurais da região de Sete Lagoas-MG, sobre o meio ambiente, 2008-2009. Dissertação (Mestrado em Ciência Animal). Universidade Federal de Minas Gerais. Belo Horizonte, 2010, 79 p. Disponível em:

http://www.bibliotecadigital.ufmg.br/dspace/bitstream/handle/1843/SMOC9HDJWH/disserta o fernanda menezes.pdf?sequence=1 Acesso em: 28 de junho 2017.

MENDES, C. J.; NEVES, C. U.; BERGER, R. Áreas de preservação permanente e reserva legal: Percepção dos proprietários rurais do município de Otacílio Costa, SC. Revista Floresta, Universidade Federal de Paraná, Curitiba, v. 42, n. 4, p. 671-682, 2012.

https://doi.org/10.5380/rf.v42i4.17283

MERLEAU-PONTY, M. Fenomenologia da percepção. Tradução de: Carlos Alberto Ribeiro de Moura. 2ª ed. São Paulo: Martins Fontes, 1999.

NASCIMENTO, T. V. do; FERNANDES, L. L. Mapeamento de uso e ocupação do solo em uma pequena bacia hidrográfica da Amazônia. Ciência e Natura, Santa Maria, v.39 n.1, 2017, Jan - abr, p. 170-178. https://doi.org/10.5902/2179460X21737

OLIVEIRA, R. R.; BARROS, J. D. S.; SILVA, M. F. P. Desertificação e degradação ambiental: percepção dos agricultores no município de Cachoeira dos Índios/PB. Revista Polêmica, Universidade do Estado de Rio de Janeiro-RJ, v. 11, n. 2, p. 244-251, 2012. https://doi.org/10.12957/polemica.2012.3096.

OKAMOTO, J. Percepção Ambiental e Comportamento. São Paulo: Plêiade, 1996, 200 p.

PEREIRA, L. C. Uso e conservação de nascentes em assentamentos rurais. Dissertação (Mestrado em Engenharia Civil). Universidade Federal de Pernambuco. Recife, 2012, 187 p.

PERIPOLLI, O. J.; ZOIA, A. O fechamento das escolas do campo: o anúncio do fim das comunidades rurais/camponesas. ECS, Sinop, v. 1, n.2, p. 188-202, 2011. Disponível em:

http://sinop.unemat.br/projetos/revista/index.php/educacao/article/viewFile/435/273 Acesso em 13 de outubro 2018. 
PRUDENTE JÚNIOR, A. C.; AMÉRICO, J. H. P.; CARVALHO, S. L.; LIMA, E. A. C. F. Agricultura e meio ambiente: concepção ambiental de alguns produtores rurais da região de Bauru-SP. In: Congresso Nacional de Meio Ambiente Anais [...]. Poços de Caldas: ABF, 2014. Disponível em: meioambientepocos.com.br/portal/anais/2014/index.php> Acesso em: 12 de setembro 2018.

REBOUÇAS, A. da C.; TUNDISI, J. G.; BRAGA, B. (Orgs.) Águas doces no Brasil: capital ecológico, uso e conservação. 3aㅡ ed. São Paulo: Escrituras Editora, 2006.

SILVA, L. N. P. da. Bacia hidrográfica do Córrego das Pitas-MT: Dinâmica fluvial e o processo de ocupação, como proposta de gestão dos recursos hídricos. Dissertação (Mestrado em Ciências Ambientais). Universidade do Estado de Mato Grosso. 2009, 146 p.

SOUZA, A. B. A. de.; CARVALHO, S. L.; LIMA, E. A. C. F. Percepção ambiental de proprietários rurais do município de Castilho. Periódico Eletrônico. Fórum Ambiental da Alta Paulista, Tupã-SP, Vol. 11, N. 4, 2015. https://doi.org/10.17271/198008271142015

SUERTEGARAY, D. M. A. Poética do espaço geográfico: em comemoração aos 70 anos da AGB. GEOUSP - Espaço e Tempo, São Paulo, n. 18, pp. 09 - 19, 2005. https://doi.org/10.11606/issn.21790892.geousp.2005.73969

TUAN, Y. F. Topofilia: um estudo da percepção, atitudes e valores do meio ambiente. Rio de Janeiro: Difusão Editorial, 1980.

TUCCI, C. E. M. Hidrologia: ciência e aplicação. $2^{a}$ ed. Porto Alegre: Editora da UFGS: ABRH. 2001.

TUNDISI, J. G.; MATSUMURA-TUNDISI, T.; RODRÍGUEZ, S. L. Gerenciamento e Recuperação das Bacias Hidrográficas dos Rios Itaqueri e do Lobo e da Represa Carlos Botelho (LoboBroa). IIE, IIEGA, PROAQUA, ELEKTRO, 2003.TUNDISI, J. G. Água no século 21: enfrentando a escassez. RIMA/IIE, 2003, $247 \mathrm{p}$.

VASCO, A.; ZAKREVSKI, S. O estado da arte das pesquisas sobre percepção ambiental no Brasil. Revista Perspectiva, Erechim. v. 34, n. 125, p. 17-28, mar. 2010. Disponível em:

http://www.uricer.edu.br/site/pdfs/perspectiva/125 71.pdf Acesso em: 18 de setembro 2017.

WHYTE, A. La perception de L'environnement: lignes directrices méthodologiques pour les études sur le terrain. Notes techniques du MAB 5. Paris: UNESCO. 1978, 134 p.

WINCK, A. C.; DALLA PASQUA, S.; FISCHER, A.; GIANEZIN, M. Processo sucessório em propriedades rurais na Região Oeste de Santa Catarina. Revista da Universidade Vale do Rio Verde, Três Corações, v. 11, n. 2, p.115-127, 2013. http://dx.doi.org/10.5892/ruvrd.v11i2.115127.

Recebido em: 25/05/2019

Aceito para publicação em: 09/03/2020 